\title{
Hubungan Antar Karakter Pertumbuhan dan Komponen Hasil Tanaman Terung (Solanum melongena L.) di Lahan Gambut
}

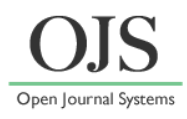

\author{
Dia Novita Sari*, Andreani Kinata, Edi Susilo, Eny Rolenti Togatorop, Parwito \\ Program Studi Agroteknologi, Fakultas Pertanian, Universitas Ratu Samban, \\ Jl. Sudirman No.87, Gn. Alam, Arga Makmur, Kabupaten Bengkulu Utara, Bengkulu 38618, Indonesia \\ *Email: dians2490@gmail.com
}

DOI: https://doi.org/10.33369/pendipa.5.3.379-383

\begin{abstract}
[Correlation between growth characters and yield components in peatland]. Utilization of peatlands can increase the production of eggplant (Solanum melongena L.). In addition, it also carries out variety assembly to produce high yielding adaptive varieties on peatlands. The research objective was to see the relationship between growth characters and yield components of eggplant. The research was conducted in Medan Baru, Muara Bangkahulu District, Bengkulu City. The experiment was carried out using a randomized complete block design on one factor with 3 replications. The factor used the Bengkulu local eggplant variety. The results showed that the character of plant height was positive correlation and very significant to the character of dichotomous height and stem diameter. Flowering age was very significant positive correlation with harvest age and significant negative correlation with fruit weight per plant. Harvest age was very significant negative correlation with fruit weight per plant. Weight per fruit was very significant positive correlation with fruit length and fruit weight per plant. Fruit length was negative correlation with maximum fruit diameter and a very significant positive correlation with fruit weight per plant.
\end{abstract}

Keywords: Correlation; character; Solanum melongena L.

\begin{abstract}
ABSTRAK
Pemanfaatan lahan gambut dapat meningkatkan produksi tanaman terung (Solanum melongena $\mathrm{L}$.). Selain itu, juga melakukan perakitan varietas untuk menghasilkan varietas unggul yang adaptif dan berproduksi tinggi di lahan gambut. Penelitian bertujuan untuk melihat hubungan antar karakter pertumbuhan dan komponen hasil tanaman terung. Penelitian dilakukan di Medan Baru Kecamatan Muara Bangkahulu Kota Bengkulu Kota Bengkulu. Penelitian menggunakan rancangan kelompok lengkap teracak (RKLT) faktor tunggal dan diulang sebanyak tiga ulangan. Faktor yang digunakan adalah varietas terung lokal Bengkulu. Hasil penelitian menunjukkan bahwa karakter tinggi tanaman berkorelasi dan sangat nyata terhadap karakter tinggi dikotomus dan diameter batang. Umur berbunga berkorelasi positif dan sangat nyata terhadap umur panen dan berkorelasi negatif sangat nyata pada bobot buah per tanaman. Umur panen berkorelasi negatif sangat nyata terhadap bobot buah per tanaman. Bobot per buah berkorelasi positif dan sangat nyata terhadap panjang buah dan bobot buah per tanaman. Panjang buah berkorelasi negatif terhadap diameter buah maksimal dan berkorelasi positif sangat nyata terhadap bobot buah per tanaman.
\end{abstract}

Kata kunci: Korelasi; sifat; Solanum melongena L.

\section{PENDAHULUAN}

Tanaman terung (Solanum melongena L.) merupakan salah satu produk hortikultura yang sangat berguna bagi kesehatan tubuh. Lestari et al. (2016) menyatakan bahwa mengkonsumsi buah terung dapat berguna dalam menangkal radikal bebas karena banyak mengandung antioksidan serta dapat menurunkan kolesterol. Selain itu, terung juga banyak mengandung nilai gizi diantaranya serat, mineral, lemak, vitamin, 
dan protein (Arivalagan et al., 2013: Ayaz et al., 2015: Rodriguez-Jimenez et al., 2018: Suzanna et al., 2019). Fakta ini diduga kuat menjadi alasan utama semakin meningkatnya permintaan terung di Indonesia, terbukti bahwa terung masuk ke dalam jajaran sayuran yang sangat digemari (BPS, 2017).

Menurut data Badan Pusat Statistik, produksi terung secara nasional dalam tiga tahun terakhir menunjukkan tren meningkat (Tabel 1). Kenyataan ini perlu dipertahankan dan ditingkatkan. Perluasan areal tanam merupakan jawaban terbaik yang bisa dipilih untuk tetap menjaga kestabilan dan meningkatkan produksi terung. Akan tetapi, ketersediaan lahan pertanian subur semakin berkurang dampak dari semakin tingginya alih fungsi lahan. Solusi terbaik untuk permasalahan tersebut adalah dengan memanfaatkan lahan gambut.

Tabel 1. Produksi Terung di Indonesia pada Tahun 2017, 2018 dan 2019

\begin{tabular}{lccc}
\hline & \multicolumn{3}{c}{ Produksi (ton per tahun) } \\
\cline { 2 - 4 } & $\mathbf{2 0 1 7}$ & $\mathbf{2 0 1 8}$ & $\mathbf{2 0 1 9}$ \\
\hline Nasional & 535,419 & 551,552 & 575,393 \\
\hline
\end{tabular}

Sumber: BPS, 2020.

Di negara tropis, Indonesia memiliki lahan gambut paling luas yaitu pada kisaran angka 21 juta ha atau 10,8\% dari luas daratan Indonesia. Ratmini (2012) melaporkan bahwa sebaran lahan gambut di Indonesia adalah 35\% (Sumatera), $32 \%$ (Kalimantan), 30\% (Papua), dan 3\% (Sulawesi, Halmahera dan Seram). Upaya dalam pemanfaatan lahan gambut, tingkat ketebalan gambut merupakan pertimbangan yang perlu diperhatikan. Lahan gambut dengan ketebalan 50-100 cm merupakan lahan gambut yang tergolong dangkal atau tipis (Wahyunto et al. 2014). Masganti et al. (2017) menyampaikan bahwa lahan gambut dangkal sangat berpotensi dalam produksi tanaman pangan dan hortikultura. Fakta ini menjadikan bahwa lahan gambut memiliki potensi untuk pengembangan budidaya tanaman terung.

Pada tahap awal pengembangan terung di lahan gambut, terlebih dahulu melakukan evaluasi keragaan awal tanaman. Hasil evaluasi akan diperoleh kandidat tetua yang akan dikembangkan untuk dirakit menjadi varietas unggul yang adaptif di lahan gambut. Evaluasi keragaan ditempuh dengan memanfaatkan program pemuliaan tanaman, khususnya mempelajari hubungan antar karakter. Untuk mempelajari hubungan antar karakter tanaman dapat menggunakan korelasi. Rofidah et al, (2018) menyatakan bahwa dasar program seleksi yang eketif adalah dengan mengetahui korelasi antar karakter atau sifat. Jika korelasi nyata artinya peningkatan satu karakter akan meningkatkan karakter yang lain. Jika antar karakter berkorelasi tidak nyata artinya diantara karakter tersebut bertindak saling bebas terhadap karakter lainnya. Tujuan penelitian adalah untuk melihat hubungan antar karakter pertumbuhan dan komponen hasil tanaman terung.

\section{METODE PENELITIAN}

Percobaan telah dilakukan pada bulan Juli hingga November 2020. Percobaan dilakukan di kebun percobaan Medan Baru Kecamatan Muara Bangkahulu Kota Bengkulu. Percobaan menggunakan rancangan kelompok lengkap teracak (RKLT) faktor tunggal dan diulang sebanyak tiga kali. Faktor yang digunakan adalah varietas terung lokal Bengkulu.

Penyemaian bibit dilakukan selama 4 minggu hingga bibit memiliki 4-5 helai daun. Kegiatan penyemaian menggunakan tray persemaian dan media tanam yang digunakan adalah kompos. Bibit ditanam ke petak berukuran $100 \mathrm{~cm}$ x $250 \mathrm{~cm}$ dengan jarak tanam $50 \mathrm{~cm}$. Keseluruhan petak percobaan dalam penelitian adalah sebanyak 15 dan setiap petak diamati sebanyak 5 tanaman sampel yang mewakili populasi tanaman dalam petak.

Pemeliharaan tanaman meliputi pembersihan gulma dan melakukan pembumbunan. Penyiraman dilakukan dan disesuaikan dengan kondisi lapangan. Pemupukan dilakukan saat tanam dan dilakukan setiap satu minggu sekali hingga tanaman panen. Pupuk yang digunakan adalah pupuk NPK Mutiara (16:16:16). 
Pengendalian hama dan penyakit dilakukan secara manual dan menggunakan insektisida. Pemanenan dilakukan jika buah terung telah memiliki kriteria panen konsumsi atau panen pasar. Panen dilakukan secara maual dan panen dilakukan berpriode setiap satu minggu sekali hingga 6 minggu setelah umur panen.

Pengamatan dilakukan terhadap karakter tinggi tanaman $(\mathrm{cm})$, tinggi dikotomus $(\mathrm{cm})$, diameter batang ( $\mathrm{mm})$, umur berbunga (hst), umur panen (hst), bobot per buah (g), panjang buah $(\mathrm{cm})$, diameter buah maksimal $(\mathrm{mm})$, dan bobot buah per tanaman $(\mathrm{g})$.

Data hasil pengamatan dianalisis dengan uji korelasi sederhana menggunakan rumus (Mattjik dan Sumertajaya, 2013):

$$
r=\frac{n \sum x y-\left(\sum x\right)\left(\sum y\right)}{\sqrt{\left[n x^{2}-(x)^{2}\right]\left[n \sum y^{2}-9 \sum y\right)^{2}}}
$$

Uji signifikasi koefisien korelasi antara 2 karakter digunakan uji t student:

$$
t=\frac{r \sqrt{n}-2}{\sqrt{1}-r^{2}}
$$

Apabila koefisien korelasi $0<\mathrm{r}<1$, maka dua karakter berkorelasi positif dan -1 $\leq \mathrm{r}<0$, maka dua karakter bersifat negatif.

\section{HASIL DAN PEMBAHASAN}

Angka yang menunjukkan arah dan kuatnya hubungan antar karakter yang dinyatakan dalam bentuk hubungan positif dan negatif adalah korelasi. Koefisien korelasi menyatakan kuatnya hubungan antar karakter (Rini et al., 2018). Putri et al, (2017) menyatakan untuk mengukur keeratan hubungan dua karakter dapat menggunakan korelasi. Koefisien korelasi dapat bernilai negatif maupun positif sehingga kisaran nilai berada antara +1 dan -1 , nilai koefisien korelasi 0 menunjukkan bahwa antar karakter tidak memiliki hubungan (Acquaah, 2009). Koefisien korelasi antar karakter tanaman terung disajikan pada Tabel 2 .

Hasil analisis korelasi memperlihatkan bahwa karakter berupa tinggi tanaman berkorelasi positif dan sangat nyata terhadap tinggi dikotomus dan diameter batang. Hal ini dapat diartikan bahwa peningkatan tinggi tanaman sampai batas tertentu akan diikuti oleh peningkatan tinggi dikotomus dan diameter batang tanaman. Karakter tinggi tanaman berkorelasi negatif dan tidak nyata terhadap karakter umur berbunga, umur panen, bobot per buah, panjang buah dan diameter buah maksimal, sedangkan terhadap karakter bobot buah pertanaman memiliki korelasi yang positif tidak nyata. Karakter tinggi dikotomus berkorelasi positif dan tidak nyata terhadap karakter diameter batang, umur berbunga, umur panen, dan panjang buah dan berkorelasi negatif tidak nyata terhadap karakter bobot per buah, diameter buah maksimal dan bobot buah per tanaman. Karakter diameter batang berkorelasi positif dan tidak nyata terhadap bobot per buah, panjang buah, dan bobot buah per tanaman, sedangkan terhadap karakter umur berbunga, umur panen dan diameter buah maksimal memiliki korelasi yang negatif tidak nyata.

Karakter umur berbunga berkorelasi positif dan sangat nyata terhadap umur panen. Hasil yang serupa ditemukan pada penelitian Putri et al. (2017). Umur berbunga berkorelasi negatif dan sangat nyata terhadap karakter bobot buah per tanaman, sedangkan berkorelasi negatif tidak nyata terhadap bobot buah per buah dan panjang buah. Umur berbunga berkorelasi positif dan tidak nyata terhadap karakter diameter buah maksimal. Untuk karakter umur panen berkorelasi negatif dan sangat nyata terhadap karakter bobot buah per tanaman. Ini dapat diartikan bahwa semakin cepat panen maka bobot buah yang dihasilkan akan semakin berkurang. Umur panen berkorelasi negatif dan tidak nyata terhadap bobot per buah dan panjang buah, dan berkorelasi positif yang tidak nyata terhadap diameter buah maksimal. 
Tabel 2. Koefisien Korelasi Komponen Pertumbuhan dan Komponen Hasil

\begin{tabular}{llllllllll}
\hline Karakter & TT & TD & DB & UB & UP & BPB & PB & DBM & BBPT \\
\hline TT & 1 & $0,527 * *$ & $0,657 * *$ & $-0,26$ & $-0,205$ & $-0,114$ & $-0,03$ & $-0,117$ & 0,047 \\
TD & & 1 & 0,299 & 0,161 & 0,239 & $-0,002$ & 0,192 & $-0,314$ & $-0,028$ \\
DB & & & 1 & $-0,207$ & $-0,168$ & 0,092 & 0,165 & $-0,302$ & 0,16 \\
UB & & & & 1 & $0,979 * *$ & $-0,249$ & $-0,207$ & 0,019 & $-0,528 * *$ \\
UP & & & & & 1 & $-0,299$ & $-0,254$ & 0,062 & $-0,529 * *$ \\
BPB & & & & & & 1 & $0,867 * *$ & $-0,295$ & $0,711 * *$ \\
PB & & & & & & & 1 & $-0,537 * *$ & $0,804 * *$ \\
DBM & & & & & & & & 1 & $-0,249$ \\
BBPT & & & & & & & & & 1 \\
\hline Ketan
\end{tabular}

Keterangan: $* *=$ sangat nyata, $\mathrm{TT}=$ tinggi tanaman, $\mathrm{TD}=$ tinggi dikotomus, $\mathrm{DB}=$ diameter batang, $\mathrm{UB}=$ umur berbunga, $\mathrm{UP}=$ umur panen, $\mathrm{BPB}=$ bobot per buah, $\mathrm{PB}=$ panjang buah, $\mathrm{DBM}=$ diameter buah maksimal, BBPT $=$ bobot buah per tanaman.

Karakter bobot per buah berkorelasi positif dan sangat nyata terhadap karakter panjang buah dan bobot buah per tanaman. Kenyataan ini memiliki arti bahwa semakin berat bobot per buah maka kemungkinan buah yang dihasilkan semakin besar sehingga bobot buah per tanaman juga samkin berat. Akan tetapi, bobot per buah berkorelasi negatif dan tidak nyata terhadap karakter diameter buah maksimal. Karakter panjang buah berkorelasi positif dan sangat nyata terhadap karakter bobot buah per tanaman. Ini memiliki arti bahwa semakin panjang buah yang dihasilkan maka akan semakin berat bobot buah per tanaman yang dihasilkan. Akan tetapi, karakter panjang buah berkorelasi negatif dan sangat nyata terhadap diameter buah maksimal. Ini mengartikan bahwa semakin panjang buah yang dihasilkan maka semakin kecil diameter buah maksimal, dengan kata lain buah yang dihasilkan dalam penelitian ini adalah tidak terlalu panjang dan tidak terlalu besar. Karakter diameter buah maksimal berkorelasi negatif dan tidak nyata terhadap karakter bobot buah per tanaman.

Secara umum, korelasi antara komponen pertumbuhan terhadap hasil (bobot buah per tanaman) adalah berkorelasi positif dan tidak nyata. Berbeda dengan komponen perkembangan yaitu karakter umur berbunga dan umur panen berkorelasi negatif dan sangat nyata terhadap hasil. Untuk komponen hasil seperti karakter bobot per buah dan panjang buah memiliki korelasi positif dan sangat nyata terhadap hasil (bobot buah per tanaman). Kenyataan ini memiliki arti bahwa karakter tersebut saling mempengaruhi. Wardana et al. (2015) menyatakan bahwa seleksi akan sangat efektif jika nilai koefisien korelasi tinggi karena sifat atau karakter yang satu dengan yang lainnya saling mempengaruhi.

\section{KESIMPULAN}

Berdasarkan analisis korelasi maka dapat disimpulkan bahwa karakter umur berbunga dan umur panen berkorelasi negatif dan sangat nyata terhadap bobot buah per tanaman, bobot per buah dan panjang uah berkorelasi positif dan sangat nyata terhadap bobot buah per tanaman. Karakter yang dapat dijadikan sebagai acuan dalam pengembangan budidaya terung di lahan gambut adalah umur berbunga, umur panen, bobot per buah, dan panjang buah.

\section{UCAPAN TERIMA KASIH}

Terima kasih disampaikan kepada Kementrian Riset dan Teknologi yang telah 
memberikan dana untuk pelaksanaan penelitian melalui skema pendaaan Penelitian Dosen Pemula (PDP) dengan nomor kontrak 802/SP2H/LT/MONO/LL2/ 2020 .

\section{DAFTAR PUSTAKA}

Acquaah, G. (2009) Principles of Plant Genetics and Breeding. John Wiley \& Sons, Hoboken, New Jersey, USA.

Arivalagan, M., Bhardwaj, R., Gangopadhyay, K.K., Prasad, T.V., Sarkar, S.K. (2013) Mineral Composition and Their Genetic Variability Analysis in Eggplant (Solanum melongena L.) germplasm, Journal of Applied Botany and Food Quality, 86: 99103.

Ayaz, F.A., Colak, N., Topuz, M., Tarkowski, P., Jaworek, P., Seiler, G., Inceer, H. (2015) Comparison of Nutrient Content in Fruit of Commercial Cultivars of Eggplant (Solanum melongena L.), Pol. J. Food Nutr. Sci. 65(4): 251-259.

[BPS] Badan Pusat Satistik. (2017) Konsumsi Buah dan Sayur Susenas Maret 2016, Diambil dari http://www.gizi.depkes.go.id.

[BPS] Badan Pusat Statistik. (2020) Produksi Tanaman Sayuran Terung, Diambil dari https://www.bps.go.id/site/resultTab.

Lestrai, S.B., Pratamaningtyas, S., Sugiarti, U. (2016) Evaluasi Keragaman dan Potensi Genetik 7 Genotipa Terung (Solanum melongena L.), Jurnal Ilmu-Ilmu Pertanian 10(1): 31-40.

Masganti., Anwar, K., Susanti, M.A. (2017) Potensi dan Pemanfaatan Lahan Gambut Dangkal untuk Pertanian, Jurnal Sumberdaya Lahan, 11(1): 43-52.

Mattjik, A.A., Sumertajaya, I.M., (2013) Perancangan Percobaan dengan Aplikasi SAS dan Minitab, IPB Press, Bogor.

Putri, F.D., Sobir, Syukur, M., Maharijaya, A. (2017) Pengembangan Kriteria Seleksi untuk Perakitan Terung (Solanum melongena L.) Berdaya Hasil Tinggi, J. Agron. Indonesia, 45(2): 182-187.
Ratmini, S. (2012) Karakteristik dan Pengelolaan Lahan Gambut untuk Pembangunan Pertanian, Jurnal Lahan Sipoptimal, 1(2): 197-206.

Rini, F.M., Wirnas, D., Nindita, A. (2018) Keragaman Populasi F2 Padi (Oryza sativa L.) pada Kondisi Cekaman Suhu Tinggi, Bul. Agrohorti, 6(3): 326-335.

Rodriguez-Jimenez, J.R., Amaya-Guerra, C.A., Baez-Gonzales, J.G., Aguilera-Gonzales, C., Urias-Orona, V., Nino-Medina, G. (2018) Physicochemical, Functional, and Nutraceutical Properties of Eggplant Flours Obtained by Different Drying Methods, Molecules, 23: 1-13.

Rofidah, N.I., Yulianah, I., Repatijarti. (2018) Korelasi Antara Komponen Hasil dengan Hasil pada Populasi F6 Tanaman Cabai Merah Besar (Capsicum annuum L.), Jurnal Produksi Tanaman, 6(2): 230-235.

Suzanna, A., Wijaya, M., Fadilah, R. (2019) Analisis Kandungan Kimia Buah Terong Belanda (Cyphomandra betacea) Setelah Diolah Menjadi Minuman Ringan, Jurnal Pendidikan Teknologi Pertanian, 5:S21S36.

Wahyunto., Nugroho, K., Ritung, S., Sulaiman, Y. (2014) Indonesian peatland map: method, certainty, and uses. Hlm 81-96. Dalam Wihardjaka et al. (Eds.), Prosiding seminar nasional pengelolaan berkelanjutan lahan gambut terdegradasi untuk mitigasi GRK dan peningkatan nilai ekonomi, Balitbangtan, Kementerian Pertanian.

Wardana, C.K., Satyana, A., Sitompul, S.M. (2015) Keragaman Hasil, Heritabilitas dan Korelasi F3 Hasil Persilangan Kedelai (Glycine $\max$ L. Merril) Varietas Anjasmoro dengan Varoetas Tanggamus, Grobogan, Galur AP dan UB, Jurnal Produksi Tanaman, 3(3): 182-188. 